\title{
Roles of Rivers State Community Affairs Department in Conflict Resolution between Host Communities and Oil-Companies
}

\author{
Franklin Eziho Nlerum, Mercy Dakoru Epepe \\ Department of Agricultural and Applied Economics/Extension, Rivers State University of Science and \\ Technology, Nkpolu-Oroworukwo, Port Harcourt, Nigeria \\ Email: frankezi@yahoo.com
}

Received 26 November 2015; accepted 12 December 2015; published 17 December 2015

Copyright (C) 2015 by authors and OALib.

This work is licensed under the Creative Commons Attribution International License (CC BY). http://creativecommons.org/licenses/by/4.0/

(c) (7) Open Access

\begin{abstract}
The study analyzed the roles performed by the Rivers State community affairs department in conflict resolution between host communities and oil-companies in Rivers State, Nigeria. Multi-stage sampling, involving the consensus, random sampling and snowball techniques were used in selecting the sample size of 139 respondents which was used for the study. The questionnaire and interview schedule were used in the elicitation of data. Data were analyzed with percentage, mean and analysis of Variance (ANOVA). Result shows that the major roles performed by the Department were mediating (3.85), facilitating (3.42) and organization of workshops (3.08). Further result indicated that while the Department (3.08) itself and oil companies (3.49) accepted the roles performed by the Department as being satisfactory, the community (2.74) respondents were not satisfied. The major constraints to the roles performed by the Department were inaccessibility into community of conflicts, lack of funds and limited resources to work with. Good access into community of conflict, sufficient funding and resources to work with was recommended for enhanced roles of the Department in Rivers State.
\end{abstract}

\section{Keywords}

Community Affairs Department, Conflict, Conflict Resolution, Host Communities, Oil-Companies, Rivers State

Subject Areas: Sociology

\section{Introduction}

\subsection{Concept of Conflict and Conflict Resolution}

Conflict is a confrontation between two or more opposing parties aspiring towards incompatible or competitive

How to cite this paper: Nlerum, F.E. and Epepe, M.D. (2015) Roles of Rivers State Community Affairs Department in Conflict Resolution between Host Communities and Oil-Companies. Open Access Library Journal, 2: e2198.

http://dx.doi.org/10.4236/oalib.1102198 
means Miller and King [1]. Conflict has also been defined by Ekong [2] as that form of social interaction in which the actors seek to obtain scarce reward by weakening or even eliminating other contenders. Eliminating contenders occur when a conflict has assumed a war situation. Miller [3] defined conflict resolution as a variety of approaches aimed at terminating conflicts through the constructive solving of problems, which is distinct from management or transformation of conflict. According to Dokun [4], the term conflict resolution, currently has formed a major research programme in the field of conflict and peace studies. Subsequently, several scholars of conflict and peace studies have defined conflict resolution in different ways. According to Swanstron and Weissman [5], conflict resolution is the resolution of the underlying incompatibilities in a conflict and mutual acceptance of each party's existence. They distinguished conflict resolution from conflict management. To them, conflict management is the measure that limit, mitigate and/or contain a conflict without necessarily resolving it. This distinction to them is necessary because often times, most people confused conflict resolution with conflict management. Both terms are necessary to achieve positive result [6]. Swanstrom and Weissman [5], further explained that conflict resolution could be both formal and informal. It can either aim at resolving or terminating conflict in an open and predictable process in accordance with legal principles or focus on efforts to increase co-operation among the parties to a conflict and deepen their relationship by addressing the conditions that led to the dispute, fostering positive attitude and allaying distrust through reconciliation initiatives, and building or strengthening institutions and process through which the parties interact.

Conflict resolution tends to emphasize intervention by third parties working with conflicting parties to foster new thinking and new relationship. The term conflict resolution refers to an outcome in which the issues in an existing conflict are satisfactorily dealt with through a solution that is mutually acceptable to the parties, selfsustaining in the long-run and productive of new, positive relationship between parties that were previously hostile and adversaries [7].

\subsection{Rivers State Department of Community Affairs}

The Rivers State Department of Community Affairs was established for the sole purpose of handling conflict matters in the State. According to its policy objectives, the establishment of the Department is said to have been traced down to the reason for the creation of the then Rivers State Community Relations Bureau in 1999 by the then governor Peter Odili's led administration as a result of the incessant communal crisis that almost engulfed Rivers State in 1999.

Upon its creation, the Bureau was charged with the responsibilities of handling inter-community conflicts, intra-community conflicts, addressing all legal issues between communities and companies with legitimate business investment in the State. The Bureau was created with two units namely; Community Development Unit; which was charged with the responsibility of carrying out community development programmes in the state, and a Conflict Resolution Unit which is now known as Department of Community Affairs which was charged with the responsibility of resolving conflict matters in the state.

The establishment of the Department of Community Affairs in 2005, was to help create a better conducive environment and harmonious relationship among the people of Rivers State in order to ensure the needed peace in the Land so that the people can benefit maximally from the activities of the companies around them.

In the past fifteen (15) years or more, conflict between oil companies and their host communities have become one of the most rampant and violent type of conflict confronting the people of Rivers State and the Niger Delta region of Nigeria in general [8].

In recent times, host community-oil company conflicts have assumed an unprecedented dimensions as the people in this region seemed to have shunned amicable options of resolution in favour of the use of force and violence. It has been rightly observed that there has been an increasing unrest in the Niger Delta in recent years, as local people have demanded greater control over their natural resources, especially oil which is beneath their land [9].

In 2007 alone, 118 workers of oil multi-nationals were taken hostage in 24 attacks that led to four deaths [10]. Similarly, the first half of 2008, recorded 33 attacks resulting to nine deaths and 129 persons taken as hostage. Also, Ebijunu [11], observed that one of the manifestation of violence in Rivers State is kidnapping, hostage taking of oil workers and individuals, thus, worsening the security situation in the state. This clearly presents a great threat to the socio-economic and development of the people and the survival of the entire state if nothing is done, as any meaningful development cannot take place in an atmosphere of conflict. 


\subsection{Some Instances of Host Community-Oil Company Conflict Situations in Rivers State}

The report of the Niger Delta Human Development [8], has shown that there was no wide -spread youth crisis in the region until the 1990s when the Ogonis and others revolted. Several localized conflicts flared, however, those conflicts were characterized mainly by protests against oil companies. Noted as the most pronounced of these conflicts was that of Umuechem community in Rivers State where in December 1990, youths in the community demonstrated against Shell Petroleum Development Company (SPDC) to express their displeasure over the environmental impact of oil exploitation and lack of development in their area.

Also contained in the report were the following conflict situations;

- In 1992, Bonny youths against SPDC.

- In April 30, 1993, Norwa community against Will-Bros Nigerian Limited.

- In April 20, 1998 Sapien Nigeria Limited against villages in Ogba-Egbema-Ndoni Local Government Area.

- In April 1999, Ogbogu youths in Egi and ELF Oil Company.

- Choba town, in Rivers State, on October 28, 1999 was in conflict with WillBros Nigeria Limited.

The Ogoni saga, November 3, 2003 resulted from the highly unfriendly and exploitative nature of SPDC operation in Ogoni land. The Ogonis declared the company, "persona no grata", during the Ogoni celebration.

The roles of Rivers State Department of Community Affairs in order to foster peace between conflicting host communities and oil companies in the state included mediating role, facilitating role, advocacy role, relationship improvement and organization of workshops. The mediation role is the process in which an impartial third party helps the disputants to resolve their differences or plan out a transaction but does not have the power to impose a binding solution [12]. Facilitating role is the process where a third party helps in coordinating the activities of conflicting parties in terms of arranging for meetings, help the parties prevent and manage tension and assist them to the point of productive decisions. Advocacy role is the act or process of supporting a cause or proposal. An advocate pleads, defends, or supports a cause or interest of another [13]. Advocacy role involves pleading the cause of another person or group sometimes before a tribunal or judicial court.

The question that is left unanswered is, to what extent has the Department of Community Affairs played its role of the resolution of host community-oil company conflicts in the Rivers State? In view of this circumstance, the research problem of the study was to examine the role of the Department of Community Affairs in the resolution of community-oil company conflicts in the state. The research question was, what were the roles of the Department and its constraints in addressing its responsibilities in the state? The objectives of the study therefore were to ascertain the roles the Department has performed and to identify the constraints affecting the activities of the Department. The arising hypothesis was that, there is no significant variation among the respondents in the roles performed by the Department of Community Affairs in the resolution of host community-oil company conflicts in Rivers State.

\section{Research Methodology}

This study was carried out in Rivers State. Rivers State is one of the 36 states of Nigeria with the capital in Port Harcourt. Its population is $5,184,400$. The landscape is $21,850 \mathrm{sq} \cdot \mathrm{km}$ and it is bounded on the south by the Atlantic Ocean and on the North by Imo and Abia States, on the East by Akwa Ibom State and on the West by Bayelsa State.

Ebijunu [11], stated that Rivers State is known for having one of the largest economy in Nigeria, mainly because of its crude oil deposit. Agriculture is the main occupation of the Rivers people. However, It was observed that the production of oil and gas that Rivers State is most famous, and that with the enormous reserves of crude oil and natural gas, Rivers State accounts for more than $40 \%$ of Nigerian's crude oil production [11]. There are many petrochemical related industries in the state which also harbour the first refinery and the first Liquefied Natural Gas in Nigeria.

The Population of this study consisted of all the 10 staff of the Rivers State Department of Community Affairs who are directly involved in handling conflict matters in the State, five oil companies and 16 communities the Department of Community Affairs has handled their cases. From the Rivers State Department of Community Affairs [14], the five oil companies are Shell Petroleum Development Company (SPDC), Nigeria Agip Oil Company (NAOC), Chevron, Elf Nigeria Limited and Nestoil Company.

Rivers State Department of Community Affairs [14] has indicated the 16 communities which had played host to oil-companies in which the Department has intervened in Rivers State as: 


\begin{tabular}{cl}
\hline 1 & Alesa Community in Eleme Local Government Area \\
2 & Elelenwo Community in Obio\Akpor Local Government Area \\
3 & Mgbuosimiri, Rumueme Community in Obio/Akpor Local Government Area \\
4 & Edagbebri Community in Ahoada-West Local Government Area \\
5 & Oshie Community in Ahoada-West Local Government Area \\
6 & Okarki Community in Ahoada-West Local Government Area \\
7 & Obrikom Community in Ogba/Egbema/Ndoni Local Government Area \\
8 & Obite Community in Ogba/Egbema/Ndoni Local Government Area \\
9 & Obagi Community in Ogba/Egbema/Ndoni Local Government Area \\
10 & Kula Community in Akuku-Toru Local Government Area \\
11 & Ogbele Community in Ahoada-East Local Government Area \\
12 & Oru-Sangama Community in Akuku-Toru Local Government Area \\
13 & Mbodo, Aluu Community in Ikwerre Local Government Area \\
14 & Rumuekpe Community in Emuohua Local Government Area \\
15 & Oyorokoto Community in Adoni Local Government Area \\
16 & Umuechem Community in Etche Local Government Area \\
\hline
\end{tabular}

The study adopted the multi-stage sampling technique. Firstly, the consensus sampling technique was used to select all the ten staff of the Department of Community Affairs and all the five oil companies that have got conflicts with communities. The consensus sampling technique was used because the two populations were small. Three respondents were selected from each company to have fifteen respondents. For the communities, the random sampling method was used in selecting eight communities from the population of 16 communities. The selected communities were Rumuekpe from Emohua Local Government Area (LGA), Mbodo-Aluu from Ikwerre LGA, Elelenwo from Obio/Akpor LGA, Oshie and Edagberi from Ahoada-West LGA and Obagi, Obirikom and Obite from Ogba-Egbema LGA.

Twenty respondents each were selected from each of the eight communities to have a total of 160 respondents using the snowball technique. The snowball sampling technique was used since the community population was unknown. The snowball sampling method is useful for locating hard-to access populations and it can be used when no sampling frame is available [15]. The community respondents included community leaders, youths, women and men. Data for the study were obtained through the administration of the questionnaire and interview schedule. Copies of the questionnaire were used in data collection from literate respondents, while the interview schedule was used in eliciting data from the non-literate community respondents. One of the authors was responsible for the administration and retrieval of the data collection instruments.

The two questions contained in the questionnaire had 15 variables on the whole and elicited information on the roles performed by the Rivers State Department of Community Affairs and the constraints to the performance of its roles. The same sets of questions were addressed to all respondents apart from question two which was addressed to the respondents of the Department of Community Affairs only. The responses for the question on the roles performed by the Department was scored with a five-point Likert-Type Scale of unsatisfactory represented with one (1) point, poor represented with two (2) points, fair represented with three (3) points, satisfactory represented with four (4) points and very satisfactory represented with five (5) points. The cut-off mean used for decision making was 3.00 which was obtained by adding: $1+2+3+4+5=15 \div 5=3.00$.

Means which were less than 3.00 were regarded as unacceptable performance, while means which were 3.00 and above were regarded as acceptable and good performance. For the question about the constraints of the Department in the performance of its roles, the responses of the respondents were scored with frequency and analyzed by dividing the total frequency of occurrence for each variable by the total respondents, multiplied by 100 percent as used by Afolami and Ayanwale [16]. 
The internal consistency of the questionnaire was achieved with the pre-test reliability method. In carrying out this test, the questionnaire was administered to 10 mock respondents who were not part of the actual respondents of the study. After about two weeks, the questionnaire was re-administered to the same 10 respondents. The results were correlated and the Peason's Product-Moment Correlation Coefficient of 0.85 was obtained. This high and positive correlation confirmed that the questionnaire has a good consistency, meaning that it will elicit the same or almost the same kind of responses if it is administered several times to different respondents.

Out of the 185 copies of the questionnaire distributed for data collection, 139 were retrieved. The actual sample size of the study therefore was 139 respondents. This was made up of 115 from the community, 14 from the oil companies and 10 from the Department of Community Affairs. Data were analyzed with percentage, mean and the Analysis of Variance.

\section{Results and Discussion}

Results in Table 1 show that the best performed role of the Department was that of mediating with a pooled mean of 3.85. Mediating also was the best performed role from the point of view of respondents from the Communities, the Department of Community Affairs and Oil Companies with the mean scores of 3.57, 3.90 and 4.07 respectively. However, the oil companies gave the highest (4.07) credit to the mediating role performed by the Department. This finding agreed with that of [17] where the mediating method of dispute resolution was found to be significantly useful in Delta State, Nigeria. The finding also agreed with the study of [18] where the mediation method of conflict resolution was found to be very effective in managing environmental conflicts in oil producing areas of Nigeria.

\section{Roles Performed by the Department of Community Affairs}

The three groups of respondents were unanimous in accepting that the Rivers State Department of Community Affairs performed its mediating role of resolving community-oil company conflicts satisfactorily in the State.

The next major performed role of the Department with a pooled mean of 3.40 was that of facilitating reconciliation between host communities and oil-companies. Facilitating role was represented as the second best for the community, Department of Community Affairs and oil company respondents with mean scores of 3.09, 3.80 and 3.36 respectively. The third best performed role was that of organizing workshops with a pooled mean of 3.08. While this role was accepted as being satisfactory performed by respondents from the Department (3.60) and the Oil Company (3.21), it was rejected by respondents from the community (2.43). The grand mean results indicated that the community respondents rejected (2.74) the roles performed by the Rivers State Community Affairs Department as being satisfactory, while the Department (3.08) itself and oil company (3.47) respondents accepted the agency's performed roles as being satisfactory.

Table 1. Roles performed by the rivers state department of community affairs in the resolution of community-oil company conflicts.

\begin{tabular}{|c|c|c|c|c|c|c|c|c|c|c|c|c|c|c|}
\hline \multirow{2}{*}{$\mathbf{S} / \mathbf{N}$} & \multirow{2}{*}{ Roles } & \multicolumn{3}{|c|}{ Community } & \multirow{2}{*}{ 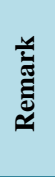 } & \multicolumn{3}{|c|}{$\begin{array}{l}\text { Rivers State Department } \\
\text { of Community Affairs }\end{array}$} & \multirow{2}{*}{ 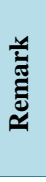 } & \multicolumn{3}{|c|}{ Oil company } & \multirow{2}{*}{ 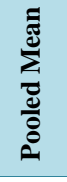 } & \multirow{2}{*}{ 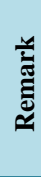 } \\
\hline & & $\mathrm{N}$ & $\begin{array}{l}\text { Total } \\
\text { Score }\end{array}$ & $\begin{array}{l}\text { Mean } \\
\text { Score }\end{array}$ & & $\mathrm{N}$ & $\begin{array}{l}\text { Total } \\
\text { Score }\end{array}$ & $\begin{array}{l}\text { Mean } \\
\text { Score }\end{array}$ & & $\mathrm{N}$ & $\begin{array}{l}\text { Total } \\
\text { Score }\end{array}$ & $\begin{array}{l}\text { Mean } \\
\text { Score }\end{array}$ & & \\
\hline 1 & Mediating role & 115 & 411 & 3.57 & A & 10 & 39 & 3.90 & A & 14 & 57 & 4.07 & 3.85 & A \\
\hline 2 & Facilitating role & 115 & 355 & 3.09 & A & 10 & 38 & 3.80 & A & 14 & 47 & 3.36 & 3.40 & A \\
\hline 3 & Advocacy role & 115 & 230 & 2.00 & $\mathrm{R}$ & 10 & 23 & 2.30 & $\mathrm{R}$ & 14 & 58 & 4.14 & 2.81 & A \\
\hline 4 & $\begin{array}{l}\text { Improve community-oil } \\
\text { company relations }\end{array}$ & 115 & 299 & 2.60 & $\mathrm{R}$ & 10 & 18 & 1.80 & $\mathrm{R}$ & 14 & 36 & 2.57 & 2.32 & $\mathrm{R}$ \\
\hline 5 & Organising workshops & 115 & 279 & 2.43 & $\mathrm{R}$ & 10 & 36 & 3.60 & $\mathrm{R}$ & 14 & 45 & 3.21 & 3.08 & A \\
\hline & Grand Mean & & & 2.74 & & & & 3.08 & & & & 3.47 & & \\
\hline
\end{tabular}

Source: Field Survey, 2013. Cut-off mean = 3.00, A = Accepted Performance, R = Rejected Performance. 
Table 2 shows the ANOVA result of the significant difference of the Community, Rivers State Department of Community Affairs, and the Oil-Companies on the role performed by the Rivers State Department of Community Affairs in resolution of community- oil company conflicts in Rivers state. The ANOVA table shows that the computed $f$ was 0.588 with a significant value of 0.436 . Since the significant value $(0.436)>0.05$ level of significance, the null hypothesis which stated that, there was no significant variation among the respondents in the roles performed by Rivers State Department of Community Affairs in resolution of community- oil company conflicts in Rivers State was accepted; This implied that the three groups of respondents did not differ significantly in their assessments of the roles performed by the Rivers State Department of Community Affairs in the resolution of Community-Oil company conflicts in the State.

The results in Table 3 shows that the highest constraints to the Department's role with $100 \%$ each were inaccessibility of staff to community of conflict, lack of funds and limited resources to work with. The second was lack of adequate training of staff with $90 \%$, while the third was lack of professionals in the Department with $80 \%$. This result indicates that the Department was faced with four major constraints.

\section{Conclusion and Recommendations}

The study has shown that the major performed role by the Rivers State Department of Community Affairs in the resolution of Community-Oil conflicts in Rivers State was that of mediating. This was followed by the facilitating role. The third role was organization of workshops for the purpose of educating disputants and the state to embrace peace and dialogue rather violent conflicts. The Oil Company and the Department itself accepted that Community Affairs Department performed its roles satisfactorily. The community on the other hand failed to accept that the Department has satisfactorily performed its roles in the state. The result of the test of hypothesis showed no significant variation between the respondents in the role performed by the Department. The Department may not have been able to satisfy the community in the roles it performed because of the problems of

Table 2. ANOVA result showing the significant difference of the role performed by the department in community-oil company conflict resolution.

\begin{tabular}{cccccc}
\hline Sources of Variation & Sum of Squares & df & Mean Square & F & Sig \\
\hline Between Groups & 0.658 & 2 & 0.329 & 0.588 & 0.436 \\
Within group & 6.715 & 12 & 0.560 & & \\
Total & 7.373 & 14 & & \\
\hline
\end{tabular}

Source: Field Survey, 2013. Grand Mean = 3.01, Alpha Level = 0.05 Significance.

Table 3. Constraints to the roles performed by the rivers state department of community affairs $(n=10)$.

\begin{tabular}{cllc}
\hline S/N & \multicolumn{1}{c}{ Constraints of roles performed } & Frequency & Percentage \% \\
\hline 1 & Lack of adequate training & 9 & 90.0 \\
2 & Socio-cultural impediment & 0 & 0.0 \\
3 & Inaccessibility to community of conflict & 10 & 100.0 \\
4 & Lack of funds & 10 & 100.0 \\
5 & Insufficient staff & 7 & 70.0 \\
6 & Limited resources to work with & 10 & 100.0 \\
7 & Unfavourable organisational policy & 2 & 20.0 \\
8 & Insufficient cooperation from oil companies & 4 & 40.0 \\
9 & Lack of professionals in the Department & 8 & 80.0 \\
10 & Insufficient cooperation from oil communities & 6 & 60.0
\end{tabular}

Source: Field Survey, 2013. Multiple Responses were allowed. 
inaccessibility to community of conflict, lack of funding and limited resources to work with. The study recommends better accessibility into conflicting communities, adequate funding and provision of enough resources to carry out the roles of the Department.

\section{References}

[1] Miller, C.E. and King, M.E. (2005) A Glossary of Terms and Concepts in Peace and Conflict Studies. End Edition, University for Peace in Africa, Geneva.

[2] Ekong, E.E. (2003) Rural Sociology: An Introduction and Analysis of Rural Nigeria. Dove Educational Publishers, Uyo.

[3] Miller, C.A. (2003) A Glossary of Terms and Concepts in Peace and Conflict Studies. University for Peace, Africa Programme, Geneva.

[4] Dokun, O.P. (2005) Conflict and Content of Conflict Resolution in Nigeria. Awolowo University Press Limited, Ile-Ife.

[5] Swanstron, N.P. and Weissman, M.S. (2005) Conflict, Conflicts Prevention, Conflict Management and Beyond: A Conceptual Exploration. A Publication of Central Asian Caucasus Institute, Silk Road Studies. www.silkroadstudies.org

[6] Zartman, W.I. (2000) Conflict Management. The Long and Short of It. SAIS Review, 20, 227-235.

[7] Mitchell, C. and Bank, M. (1998) Handbook on Conflict Resolution. The Analytical Problem-Solving Approach, London Printer.

[8] Niger Delta Human Development Report (2006). http://www.ng.undo.org/documents/Nigeria-delta-hdr.pdf

[9] Human Rights Watch (1995) Nigeria, the Ogoni Crisis: A Case Study of Military Repression in South Eastern Nigeria.

[10] Ibaba, S.I. and Philips, O.O. (2009) Resolving Militia Conflicts in the Niger Delta: The Role and Strategies of Mediation. University of Idaho. 1-18.

[11] Ebijunu, H.T. (2008) Oil Resources and Violence in Rivers State of Nigeria: Implication and the Way Forward. A Thesis submitted to European University Centre for Peace Studies, Stadschlaining/Bury, Austria.

[12] Jonah, O. (2009) Negotiation and Mediation Process. In: Ikejiani-Clark, M., Ed., Peace Studies and Conflict Resolution in Nigeria: A Reader, The Spectrum Books Limited, Ibadan, 1-631.

[13] Tomajan, K. (2012) Advocating for Nurses and Nursing. Online Journal of Issues in Nursing, 17, Manuscript 4.

[14] Rivers State Department of Community Affairs (2011) Ministry of Chieftany and Community Affai.rs, Port Harcourt.

[15] Judy, L.K. and Jerry, F. (2007) Research for Effective Social Work Practice: New Direction in Social Work. A McGraw-Hill Series.

[16] Afolami, C.A. and Ayanwale, A.O.S. (2007) Adoption Rates of Improved Maize Production Technologies in Ogun State Agricultural Development Programme Zones of Nigeria. International Journal of Food and Agricultural Research, 4, 93-109.

[17] Umunadi, E.K. (2011) The Efficacy of Mediating and Negotiation Methods for Dispute Resolution in Delta State. Sacha Journal of Policy and Strategic Studies, 1, 64-73.

[18] Folade, O.A., Ogedenghe, K. and Bickersteth, T. (2006) Managing Environmental Conflicts in the Oil Producing Areas of Nigeria. Trends in Applied Sciences Research, 1, 259-272. http://dx.doi.org/10.3923/tasr.2006.259.272 


\section{Appendix (Questionnaire)}

Department of Agriculture and Applied Economics/Extension, Rivers State University of Science and Technology, P.M.B. 5080, Port Harcourt, $9^{\text {th }}$ of May, 2013.

Dear Respondent,

I am a Masters Student of the above institution. I am carrying out a research study with the title "role of Community Affairs Department of Rivers State Government in resolution of Community-Oil Company Conflicts”. The study is purely an academic exercise. Information given by you will be used for this purpose. I therefore wish to request that you answer the questions as objectively as possible.

Thank you for cooperation.

Yours faithfully

Epepe, Mary Dakoru

\section{Questions}

1) How would you rate the roles performed so far by the Rivers State Department of Community Affairs in resolution of Community-Oil company conflict in the State? You are free to tick more than one role.

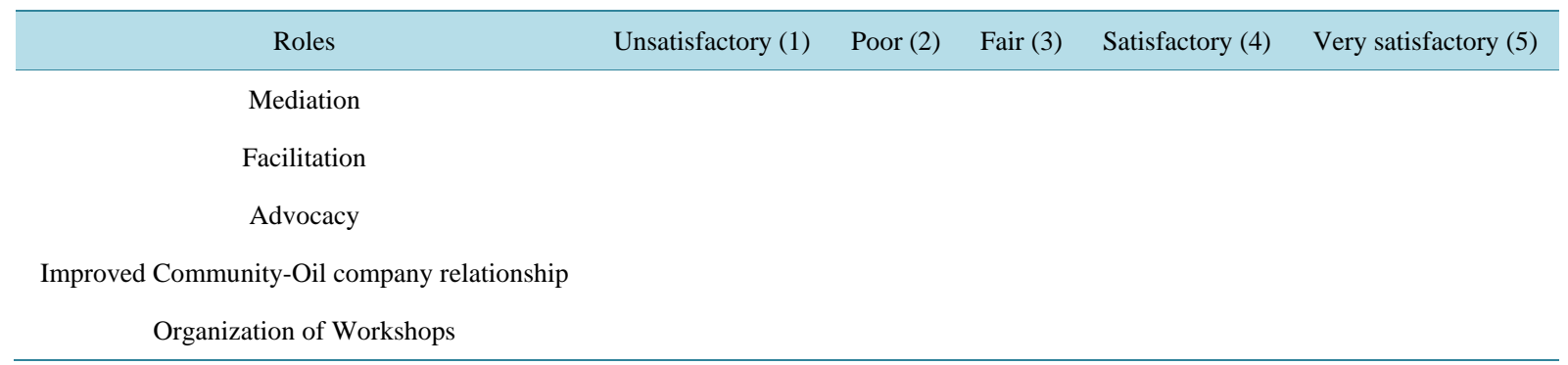

2) What are the constraints of the Department in performing its roles? You are free to tick more than one role as it applies to you. (For Department respondents only).
a) Lack of adequate training on-the-job
b) Socio-cultural impediments
c) Inaccessibility into communities
d) Lack of funds
e) Insufficient staff
f) Limited resources to work with
g) Unfavourable organizational policies
h) Insufficient co-operation from oil companies
i) Lack of professionals in the Department
j) Insufficient co-operation from oil host communities 